\title{
FREEZABILITY AND DNA INTEGRITY OF DROMEDARY CAMEL SPERMATOZOA IN SEMEN COLLECTED BY ARTIFICIAL VAGINA AND ELECTRO-EJACULATOR
}

\author{
Mostafa T.H. ${ }^{1}$, Abd El-Salaam A.M. ${ }^{1}$, Elbadry D.E. ${ }^{2}$ and Abear M. Anour ${ }^{2}$ \\ 1- Animal Production Research Institute, Agriculture Research Center, Ministry of Agriculture, Egypt, 2- \\ Animal Reproduction Research Institute, Agriculture Research Center, Ministry of Agriculture, Egypt \\ * Corresponding author:
}

\section{SUMMARY}

Two methods of semen collection from dromedary camel bulls, including electro-ejaculation (EE) versus conventional artificial vagina $(A V)$ were compared in term of their effects on reaction time, physical semen characteristics, sperm biometry, alkaline comet assay of spermatozoa, sperm freezability. Effects on concentration of testosterone, some minerals and biochemicals as well as activity of some enzymes in blood serum of camel bulls were also evaluated. Results showed that using EE significantly increased reaction time, total sperm output per ejaculate, head length and tail width of spermatozoa, total percentage of sperm head showing comet and serum aspartate transaminase (AST) activity. On the other hand, EE significantly decreased sperm cell concentration, serum cholesterol, magnesium, zinc, inorganic phosphorus and testosterone concentrations. However, ejaculate volume, percentages of total motility, forward motility, dead, abnormality and acrosome damage of spermatozoa, head width, tail length, and total length of spermatozoa, grades of comet assay, sperm freezability, concentration of total proteins and their fraction, serum $\mathrm{Na}, \mathrm{Ca}$ and $\mathrm{K}$ concentrations and activity of alanine transaminase (ALT) and alkaline phosphatase (ALP) were not affected by collection method. Electro-ejaculation is considered as a suitable and repeatable technique for semen collection from dromedary camel bulls when semen collection by conventional artificial vagina is not possible.

Kewords: Dromedary camel, semen collection method, freezability, testosterone

\section{INTRODUCTION}

The dromedary camels (Camelus dromedarius) are extremely important livestock species in the arid and semiarid zones in Africa and Asia. Camels contribute significantly to the livelihood of the pastoralists and agro-pastoralists living in the fragile environments (Abbas et al., 2000 and Tura et al., 2010). Low reproductive performance is one of the most important factors affecting camel productivity compared to other domestic species. Factors contributing to low fertility in camels are many and complex, for example; the advanced age at puberty (3-4 years) and hence late age at first calving, the limited libido of males and hence limited breeding opportunities, the relatively short breeding season. The importance of maintenance of high levels of reproduction in camel is not only for profitable production but also to provide ample opportunities for selection and genetic improvement.

Artificial insemination (AI) is a well-accepted method used to achieve faster genetic improvement in livestock species. AI is claimed to have been highly successful in Bactrian camels (Arthur, 1992), but results have been less encouraging in dromedary camels. Semen collection from camels is considered to be a difficult task because of the intra-corneal semen deposition (Franco et al., 1981) and a long copulation interval and copulation at ground level (Arthur and Tigani 1990). Refusal to serve the artificial vagina (AV), incomplete ejaculation and sand contamination are other associated problems (Aminu Deen et al., 2003).

Although AV is considered the most suitable and repeatable technique for semen collection from the males of camelids (Lichtenwalner et al., 1996), other methods of semen collection have been reported for camelids. Semen can be collected by electroejaculation (EE), intra-vaginal sponges or passeries, post-coital vaginal aspiration and fistulation of the urethra (Sumar, 1991). The two main techniques used for semen collection from the dromedary camel are $\mathrm{AV}$ and EE techniques (Lichtenwalner et al., 1996). $\mathrm{EE}$ was used when semen collection by $\mathrm{AV}$ is not possible, since the characteristics of semen recovered by EE are similar to that collected by AV (Musa et al., 1992).

Semen collection from camels using EE requires tranquility of the animal with a special restraint (Hemeida et al., 2001). Semen volume collected by $\mathrm{EE}$ is usually less than that obtained by AV, but other semen parameters are nearly similar in both techniques (Marai and Zeidan 2007 and Tibary and Momen, 1999).

Testosterone concentration in peripheral blood could be helpful in evaluating testis activity, sexual desire of animal and spermatogenesis (Hafez and Hafez, 2000). Improvement of semen collection has been considered as an important step for generalization of artificial insemination (AI) in the camel (Sieme et al., 1990). Success of AI is 
dependent on the biophysical properties of semen obtained and its capacity for dilution and storage with minimum loss of fertilizing ability. Frozen semen of camel has not been as extensively studied as that of other species (Chen et al., 1990). Cryopreservation of camel spermatozoa is inefficient, primarily owing to lack of knowledge regarding camel sperm physiology and the viscous nature of the seminal plasma (Bravo et al., 2000a). Camel spermatozoa are generally not tolerant to freezing and thawing procedures (Morton et al., 2009). The first published work on deep freezing of the camel spermatozoa dates to the late 1970s (Graham and Schmehl, 1978) using zoo camels and electro-ejaculated semen frozen in pelleted form, but the results achieved on thawing were unsatisfactory. Musa et al. (1992) modified the technique described by Westendorf et al. (1975) to compare different methods of freezing the camel semen and to test post-thawing motility, morphology and lifespan of spermatozoa.

Therefore, the present study was conducted to evaluate effect of using artificial vagina or electroejaculation as methods of semen collection on semen quality, DNA fragmentation biometry and freezability of spermatozoa, and biochemical changes in blood serum of dromedary camel bulls.

\section{MATERIAL AND METHODS}

Animals:

Total of eight male Maghrabi camels (Camelus dromedarius), aging 7 to 10 years and weighing 500$600 \mathrm{~kg}$ raised at the Animal Production Research Institute, Dokki, Giza, Egypt (Center of Studies and Development of Camel Production, Marsa Matrouh Governorate, Egypt) were used for semen collection in this study. On a daily basis, each camel received 5 $\mathrm{kg}$ concentrate feed mixture, $5 \mathrm{~kg}$ rice straw and 10 $\mathrm{kg}$ green food (Alfa alfa) twice daily, while water was offered ad libitum.

\section{Semen collection:}

Throughout the collection period, semen was collected twice a week using two techniques, artificial vagina and electro-ejaculation, from 4 animals for each semen collection technique. Throughout the collection period of semen (breeding season, January-March), ambient temperature varied between 10 and $25^{\circ} \mathrm{C}$

\section{Artificial vagina technique (AV):}

Semen was collected by a modified bovine artificial vagina as described by Zeidan (2002). Semen was collected using a long plastic sleeve sealed at one end and inserted within the latex inner lining of the AV. To keep temperature constant, the whole AV was covered with an electric warm cover. Temperature stability was controlled using a precision sensor attached to the AV. Once the male mounted the female, the prepuce was directed toward the AV opening.

\section{Electro-ejaculation technique (EE):}

On the day of semen collection, bull was secured in sternal recumbence and then turned on his side as described by Tingari et al. (1986). The animal is restrained physically with ropes and chemically by sedation with $2.5 \mathrm{ml}$ of $20 \mathrm{mg} / \mathrm{ml}$ xylazine (xylaject, Adwia co., Egypt). Electro-ejaculation was achieved by using bovine electro-ejaculator (Mini-Tube, Germany). The rectal probe was lubricated with a copious amount of jelly, to ensure good contact with the mucosa, and applying electrical impulses of 12 volts. Two sets of stimulation are generally used, each lasts for 2.5 minutes that consisted of 10-15 pulses of 3-4 seconds duration, with a rest of 2 minutes between each two series of impulses (total time of the process is 7 minutes). The collection is made into a water-jacketed flask held at the prepucial orifice with occasional milking of the prepuce to expel all the semen (Skidmore et al., 2013).

All semen collections were performed by the same operator for each technique. Duration of semen collection (reaction time) was recorded in term of the time elapsed from start of semen collection up to complete ejaculation of each camel bull.

\section{Semen evaluation:}

Immediately after semen collection by either method, ejaculate volume $(\mathrm{ml})$ was determined in graduated collection tube. Sperm motility patterns were classified as either total or forward progressive. Sperm displaying forward progressive motility when the distance traveled was greater than one body length per second, and sperm that did not display forward motility were considered oscillatory. Percentage of sperm motility was estimated subjectively on a pre-warmed slide using phase contrast microscopy (x 100).

Sperm livability was assessed using the eosinnigrosin stain by a light microscope $(400 \times)$. Live spermatozoa (unstained ones) and dead spermatozoa (stained ones) were counted in field of a total of 200 spermatozoa, then dead sperm percentage was calculated. Sperm abnormalities percentage was determined during the examination of live/dead sperm percentage at a high power magnification (400x), according to the classification adopted by Blom (1983).

Sperm cell concentration (SCC x $10^{6} / \mathrm{ml}$ ) was evaluated by Neubauer hemocytometer. Examination of the acrosome status was carried out using Giemsa stain at $37^{\circ} \mathrm{C}$ for $3 \mathrm{~h}$. The percentage of spermatozoa with intact/damage acrosome was conducted according to Watson (1975).

Total sperm output (TSO) per ejaculate was calculated as following: TSO/ejaculate=Ejaculate volume (ml) x SCC (ml).

\section{Sperm biometry:}

Biometry of spermatozoa was measured using calibrated eye-piece micrometer scale (Hemeida, 1972). Mensuration of spermatozoa biometry was carried out on sperm-abnormality smears stained by Eosin-Nigrosin stain according to Campbell et al. (1956). The parameters of the mensuration of spermatozoa included length and width of sperm head as well as length and width of sperm tail 
according to Bretschneider (1948) and Kononov (1968).

\section{Comet assay (Single cell gel electrophoresis assay):}

The alkaline comet assay of spermatozoa (Hughes et al., 1996 and 1997) was carried out. For each sample, three slides were prepared. Fully frosted glass slides were covered with $100 \mu \mathrm{l}$ of $0.5 \%$ normal melting point agarose, a cover slip was added and the agarose was allowed to solidify. The cover slips were removed and $1 \times 10^{5}$ sperm cells in $50 \mu \mathrm{l}$ PBS $(7.2$ $\mathrm{pH})$ were mixed with $50 \mu \mathrm{l}$ of $1.2 \%$ low melting point agarose and used to form the second layer. The slides with cover slips removed were then placed in lysis buffer for $1 \mathrm{~h}(2.5 \mathrm{M} \mathrm{NaCl}, 100 \mathrm{mM} \mathrm{NaEDTA}$, $10 \mathrm{mM}$ Tris, $1 \%$ Triton $\mathrm{X}$ at a $\mathrm{pH}$ value of 10 ). The slides were then incubated at $37^{\circ} \mathrm{C}$ in $100 \mu \mathrm{l} / \mathrm{ml}$ of proteinase $\mathrm{K}$ in lysis buffer overnight. After draining the proteinase $\mathrm{K}$ solution from the slides, they were placed in a horizontal electrophoresis unit filled with freshly prepared alkaline electrophoresis solution containing $300 \mathrm{mM} \mathrm{NaOH}$ and $1 \mathrm{mM}$ EDTA for 20 min to allow the DNA to denature. Electrophoresis was performed at room temperature, at $25 \mathrm{~V}(0.714$ $\mathrm{V} / \mathrm{cm}$ ) and $300 \mathrm{~mA}$, obtained by adjusting the buffer level, for $10 \mathrm{~min}$. The slides were then washed with a neutralizing solution of $0.4 \mathrm{M}$ Tris at $\mathrm{pH} 7$ to remove alkali and detergents. After neutralization, the slides were each stained with $50 \mu \mathrm{l}$ of $20 \mu \mathrm{g} / \mathrm{ml}$ ethidium bromide (Sigma) and mounted with a cover slip. All steps were carried out under yellow light to prevent further DNA damage. A total of 200 sperm cells were examined under fluorescent microscope (x 400) and the percentage of spermatozoa with COMET were recorded and categorized. The comets were classified into 4 grades (A-D) according to the tail length as was described by Shamsi et al. (2010). Different comets of spermatozoa examined in this study are presented in Fig. (1). Total percentage of sperm head showing comet was also calculated.

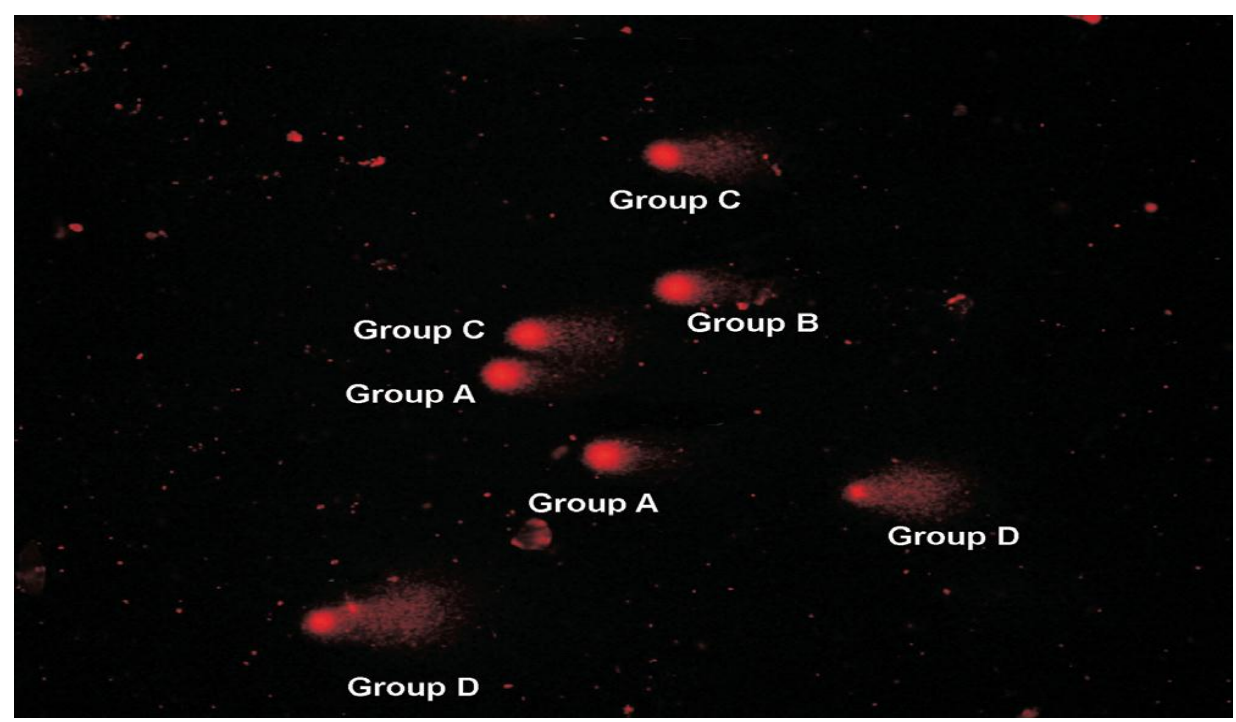

Figure 1. The alkaline comet assay of spermatozoa showing different comets. Comets having tail length $\leq \mathbf{2 0}, \mathbf{2 0 . 0 1 - 3 0 . 0 0 , 3 0 . 0 1 - 4 0 . 0 0}$ and $>40 \mu \mathrm{m}$ were classified as grades $\mathrm{A}, \mathrm{B}, \mathrm{C}$ and $\mathrm{D}$, respectively

\section{Freezing procedures:}

Semen was extended in Shotor diluent $(214.6 \mathrm{mM}$ tris, $64.2 \mathrm{mM}$ citric acid, $66.6 \mathrm{mM}$ glucose, and 49.9 $\mathrm{mM}$ fructose, $20 \% \mathrm{v} / \mathrm{v}$ egg yolk and 500I.U.ml

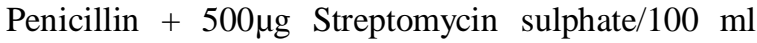
distilled water and having an osmolality level of 330 $\mathrm{mOsm} / \mathrm{kg}$ and $\mathrm{pH}$ of 6.9) (Niasari-Naslaji et al., 2006).

Extended semen ( 1 semen: 2 extender) and the final pre-freezing extension rate (1 semen: 4 extender) were used. Semen which was extended to the half of the proposed extension rate of 1 semen: 2 extender (fraction A) of the extender (non dimethyl sulfoxide, DMSO portion of the extender) at $37^{\circ} \mathrm{C}$. When the half extended semen has reached at $5^{\circ} \mathrm{C}$ (fraction $\mathrm{B}$ ) of the extender (containing of $12 \%$ DMSO) was then added at the same temperature, to obtain 6\% final DMSO concentrations and final extension rate of 1:4 (semen: extender). Extended semen with glycerol or DMSO and their combination were left at $5{ }^{\circ} \mathrm{C}$ for up to 4 hours as an equilibration period. Diluted semen was then sampled in $0.25 \mathrm{ml}$ small straws. Then, specimens were placed on a rack standing at $5 \mathrm{~cm}$ above the surface of liquid nitrogen during $5 \mathrm{~min}$ and at the surface of liquid nitrogen during $5 \mathrm{~min}$, after that straws were immersed into liquid nitrogen. After 1 week, frozen semen straws were thawed at $37{ }^{\circ} \mathrm{C}$ for 30 second. Post thawing motility was checked after $0,1,2$ and $3 \mathrm{~h}$ of incubation in a water bath at $37^{\circ} \mathrm{C}$.

\section{Analytical analysis:}

At the end of the semen collection period, blood samples were collected from the Jugular vein of camel bulls in each group (AV and EE). Blood samples were collected in clean test tubes and blood serum was separated by centrifugation of the collected blood at $15 \mathrm{~g}$ for $10 \mathrm{~min}$ then, serum was kept frozen at $-20^{\circ} \mathrm{C}$ until chemical analyses. 


\section{Biochemical concentration:}

Concentration of total proteins (Weichselbaum, 1946), albumin (Doumas and Biggs, 1976) and total cholesterol (Allain et al., 1974) was determined calorimetrically using commercial kits. However, globulin concentration was calculated by subtracting albumin from total proteins concentration.

\section{Mineral determination:}

Concentration of sodium (Trinder, 1951), calcium (Gindler, 1972), potassium (Taylor and Shea, 1930), inorganic phosphorus (Kuttner and Lichtenstein, 1930), and zinc (Willis, 1960) in blood serum were determined colourimetrically.

\section{Enzyme activity:}

Activity of aspartate transaminase (AST) and alanine transaminase (ALT) in blood serum was determined calorimetrically using commercial kits (QCA, Amposta, Spain) according to Ritman and Frankle (1957). However, activity of alkaline phosphatase (ALP) was determined calorimetrically using commercial kit (Stanbio, Texas, USA) according to Graham and Pace (1967).

\section{Hormonal assay:}

Testosterone concentration was determined by Radioimmunoassay Technique (RIA) of Coa- AbCount kits (Diagnostic Products Corporation-Los Angles, USA) according to Aubert and Chard (1977) and Pratt (1978). In addition, estrogen (estradiol 17$\beta$ ) was determined using commercial kit (Diagnostic Automation, INC.) according to Ashby et al. (1980).

\section{Statistical analysis:}

The data were statistically analyzed by completely randomize system (SAS, 2002) according to the following Model: $Y_{i j}=\mu+M_{i}+e_{i j}$, where $Y_{i j}=$ an observation, $\mu=$ the overall mean, $M_{i}=$ the fixed effect of $i^{\text {th }}$ methods of collection $(i=1,2)$, and $e_{i j}=$ random error. Significant differences between means were determined by Duncan's Multiple Range test (Duncan, 1955).

\section{RESULTS AND DISCUSSION}

\section{Effect of camel semen collection technique on:}

\section{Reaction time and physical semen characteristics:}

Results presented in Table (1) show that reaction time and total sperm output were significantly $(\mathrm{P}<0.001$ and $\mathrm{P}<0.01$, respectively) increased by about 145 and $26 \%$ with $\mathrm{EE}$ as compared to AV. Meanwhile, sperm cell concentration was significantly decreased from 297.4 for AV to $203.0 \mathrm{x}$ $10^{6}$ for EE. However, other sperm characteristics were not affected by collection technique.

It is of interest to note that increasing total sperm output $(\mathrm{P}<0.01)$ despite decreasing sperm cell concentration $(\mathrm{P}<0.001)$ for $\mathrm{EE}$ was mainly associated with insignificant increase in ejaculate volume for $\mathrm{EE}$ as compared to $\mathrm{AV}$ (7.84 vs. 5.91, $\mathrm{P}<$ or $>0.05)$.

Also, EE increased percentage of total motility and abnormality, while it decreased percentage of dead and acrosome damage of spermatozoa, but the differences were not significant (Table 1).

In comparable with the present results, reaction time of dromedary camel bulls ranges between 3 and 20 min using AV (Tibary and Anouassi, 1997), between 5 and 12 min in conventional AV method using a teaser female and 20-45 min using artificial dummy (El-Hassanein, 2003). However, no data are available on reaction time of camel using EE.

It is of interest to note that the obtained reaction time had a positive relationship with ejaculate volume in each group.

Table 1. Effect of semen collection technique on reaction time and semen characteristics of dromedary camel bull

\begin{tabular}{|c|c|c|c|}
\hline \multirow[b]{2}{*}{ Item } & \multicolumn{2}{|c|}{ Collection technique } & \multirow[b]{2}{*}{ Significance } \\
\hline & $\begin{array}{c}\text { Electro- } \\
\text { ejaculation }\end{array}$ & Artificial vagina & \\
\hline Reaction time (sec.) & $13.3 \pm 0.401$ & $5.4 \pm 0.324$ & $* * *$ \\
\hline Ejaculate volume (ml) & $7.8 \pm 0.757$ & $5.9 \pm 0.445$ & NS \\
\hline Forward progressive motility $(\%)$ & $64.0 \pm 3.674$ & $58.0 \pm 2.549$ & NS \\
\hline Forward motility $(\%)$ & $42.0 \pm 1.225$ & $42.0 \pm 3.000$ & NS \\
\hline Live/dead ratio $(\%)$ & $23.2 \pm 1.828$ & $26.4 \pm 2.580$ & NS \\
\hline Sperm abnormalities $(\%)$ & $11.0 \pm 1.095$ & $9.0 \pm 0.707$ & NS \\
\hline Acrosome damage $(\%)$ & $7.6 \pm 1.288$ & $8.4 \pm 0.509$ & NS \\
\hline Concentration $\left(\times 10^{6} / \mathrm{ml}\right)$ & $203.0 \pm 15.215$ & $297.4 \pm 9.912$ & $* * *$ \\
\hline Total sperm output (x $10^{6} /$ eiac.) & $1594.8 \pm 54.036$ & $1265.2 \pm 76.32$ & $* *$ \\
\hline
\end{tabular}

NS: Not significant. ** Significant at $\mathrm{P}<0.01$. *** Significant at $\mathrm{P}<0.001$

In accordance with the present results, several authors found an increased ejaculate volume using EE as compared to AV. Giuliano et al. (2008) found greater semen volumes in llama for EE compared to AV. Also in bovine bulls, Foote (1974) reported that semen samples collected by EE are usually of larger volume than samples obtained with AV. Barszcz et al. (2012) found that EE resulted in greater semen volume of bovine bulls. It is generally accepted that EE often yields ejaculates which are far more voluminous than those collected by means of $\mathrm{AV}$ (Mann, 1964). On the other hand, Bravo et al. (2000 b) reported that dromedary camel semen volume was higher with AV than EE (7.5 vs. $3.9 \mathrm{ml})$.

The obtained ejaculate volume in the present study by EE $(7.84 \mathrm{ml})$ was higher than the $3.9 \mathrm{ml}$ 
(Bravo et al., 2000 b) obtained by EE, and the $3.8 \mathrm{ml}$ reported earlier by Tingari et al. (1986) using EE. Under traditional AV using teaser females, higher ejaculate volume $(12.6$ and $6.87 \mathrm{ml})$ than that reported in our study $(5.4 \mathrm{ml})$ was reported by AbdelRaouf and E1-Naggar (1978) and El-Hassanein (2003), respectively. However, much higher ejaculate volume was obtained by the later author $(17.75 \mathrm{ml})$ using artificial dummy. On the other hand, the present semen volume collected by AV was higher than the $4.35 \mathrm{ml}$ reported by Tibary and Anouassi (1997).

The observed increase in ejaculate volume by EE than AV can probably be explained by the generally increased volume of accessory fluid that is associated with EE. Giuliano et al. (2008) suggested that the greater volume of semen with EE could be produced by the electrical stimulation of the accessory sex glands.

In agreement with the present results on camel semen, Bravo et al. (2000 b) found lower sperm cell concentration with AV than EE, while no differences were found in percentage of motility, livability, and acrosome abnormality of spermatozoa camel bull semen. Also in bovine bull semen, Barszcz et al. (2012) found the same trend of both techniques (AV and $\mathrm{EE}$ ) in sperm concentration, while no differences were apparent in the proportions of morphologically normal, live or actively progressive sperm.
Although the present total sperm output/ejaculate is well in accord with earlier findings which confirmed that the total sperm count of EE far exceeds values of bull semen collected by means of AV (Mann, 1964 and Foote, 1974), earlier reports showed that sperm density in semen collected by EE was almost double that which was collected by AV (Abdel-Raouf and E1-Naggar, 1978 and Tingari et al., 1986). Also, Giuliano et al. (2008) in llama reported similar total number of spermatozoa with $\mathrm{AV}$ and EE, which contrasted the present trend of differences in sperm cell concentration in our study.

Generally, using EE increased total sperm output with higher percentage of total motility, livability and intact acrosome spermatozoa, which may indicate beneficial effects of this method on collection of good quality semen in term of total count of motility, livability and fertilizing ability of camel spermatozoa. Such results indicated successful semen collection in dromedary camel bulls using $\mathrm{EE}$ as concluded in llama males (Director et al., 2007).

\section{Sperm biometry:}

Data presented in Table (2) revealed effect of semen collection technique on biometry of camel spermatozoa only in terms of increasing head length and middle piece and tail width $(\mathrm{P}<0.05)$ by $\mathrm{EE}$ as compared to AV. However, head shape index and tail/head length index were maintained by both methods.

Table 2. Effect of semen collection technique on sperm biometry of dromedary camel bull

\begin{tabular}{|c|c|c|c|}
\hline \multirow{2}{*}{ Item } & \multicolumn{2}{|c|}{ Collection technique } & \multirow{2}{*}{ Significance } \\
\hline & Electro-ejaculation & Artificial vagina & \\
\hline \multicolumn{4}{|l|}{ Sperm head $(\mu \mathrm{m})$ : } \\
\hline Length & $6.61 \pm 0.040$ & $6.16 \pm 0.017$ & $*$ \\
\hline Width & $2.97 \pm 0.07$ & $2.91 \pm 0.014$ & NS \\
\hline Shape index & 0.45 & 0.47 & - \\
\hline \multicolumn{4}{|c|}{ Sperm middle-piece and tail $(\mu \mathrm{m})$ : } \\
\hline Length & $45.9 \pm 0.033$ & $45.8 \pm 0.151$ & NS \\
\hline Width & $1.4 \pm 0.057$ & $1.1 \pm 0.020$ & $*$ \\
\hline \multicolumn{4}{|l|}{ Total sperm $(\mu \mathrm{m})$ : } \\
\hline Total length & $51.6 \pm 0.162$ & $51.6 \pm 0.149$ & NS \\
\hline Tail/head length index & 6.94 & 7.40 & - \\
\hline
\end{tabular}

Shape index $=$ Width/length ratio. Total index $=$ Tail length/head length ratio.

NS: Not significant. $* *$ Significant at $\mathrm{P}<0.01$. *** Significant at $\mathrm{P}<0.001$.

As mentioned in earlier reports, the shape of the head of camel spermatozoa is elliptical and thus differs from the general ovoid shape characteristic of spermatozoa in bovine (Tingari et al., 1986). Camel sperm is smaller than that of other domestic animals including bull, buffalo, ram, ass and stallion. Length of head and middle piece of the camel spermatozoon is shorter than those of other animals while its tail is longer than that of boar and stallion spermatozoa and shorter than all others (Tingari et al., 1986). The present sperm biometry are slightly lower than that reported by Tingari et al. (1986), who recorded that camel sperm dimensions were 5.53, 6.9, 35.6 and 48 $\mu \mathrm{m}$ for length of head, middle-piece, tail and total length of sperm, respectively.

Also, Abdel-Raouf and E1-Naggar (1976) found corresponding lengths of 5.6, 7.3, 34.2 and $47.2 \mu \mathrm{m}$, respectively.

There are no available data on camel sperm biometry as affected by EE, but according to the previous findings on sperm biometry in semen collected by AV, and these reported by both methods in this study, the present results indicated marked effect of semen collection method (AV and EE) on camel sperm biometry. 
Comet assay of spermatozoa:

Examination of the alkaline comet assay of spermatozoa (Table 3) revealed that spermatozoa showing all grades of comet assay (G A-D) were higher in semen collected by EE than in $\mathrm{AV}$, but the differences were not significant. These results were reflected in significantly $(\mathrm{P}<0.01)$ higher total percentage of sperm head showing comets in semen collected by EE than in AV. Such results indicated superiority of semen collection by EE on sperm DNA integrity of camel bulls as compared to AV method.

Table 3. Effect of semen collection technique on sperm DNA integrity of dromedary camel bull using comet assay

\begin{tabular}{|c|c|c|c|}
\hline \multirow{2}{*}{ Item } & \multicolumn{2}{|c|}{ Collection technique } & \multirow{2}{*}{ Significance } \\
\hline & Electro-ejaculation & Artificial vagina & \\
\hline Grade1 (\%) & $2.20 \pm 0.374$ & $1.80 \pm 0.339$ & NS \\
\hline Grade2 (\%) & $1.10 \pm 0.245$ & $0.70 \pm 0.339$ & NS \\
\hline Grade3 (\%) & $0.30 \pm 0.300$ & $0.30 \pm 0.122$ & NS \\
\hline Grade4 (\%) & $0.10 \pm 0.100$ & $0.10 \pm 0.100$ & NS \\
\hline Total $(\%)$ & $3.58 \pm 0.334$ & $2.80 \pm 0.489$ & NS \\
\hline
\end{tabular}

Grade A, B, C and D: Comets having tail length less than 20, 20.01-30.00, 30.01-40.00 and $>40 \mu \mathrm{m}$, respectively. NS: Not significant.

Table 4. Effect of semen collection technique on sperm motility (total and forward) in post-thawed semen of camel bull stored at $37^{\circ} \mathrm{C}$ for different times

\begin{tabular}{|c|c|c|c|}
\hline \multirow{2}{*}{ Item } & \multicolumn{2}{|c|}{ Collection technique } & \multirow{2}{*}{ Significance } \\
\hline & Electro-ejaculation & Artificial vagina & \\
\hline \multicolumn{4}{|c|}{ Total sperm motility (\%): } \\
\hline $0 \mathrm{~h}$ & $26.6 \pm 1.300$ & $30.0 \pm 4.183$ & NS \\
\hline $1 \mathrm{~h}$ & $17.8 \pm 1.158$ & $22.8 \pm 3.292$ & NS \\
\hline $2 \mathrm{~h}$ & $10.8 \pm 1.068$ & $12.8 \pm 3.292$ & NS \\
\hline $3 \mathrm{~h}$ & $3.8 \pm 0.970$ & $5.2 \pm 1.933$ & NS \\
\hline \multicolumn{4}{|c|}{ Forward sperm motility (\%): } \\
\hline $0 \mathrm{~h}$ & $22.4 \pm 1.300$ & $26.6 \pm 4.249$ & NS \\
\hline $1 \mathrm{~h}$ & $13.4 \pm 1.536$ & $17.6 \pm 4.365$ & NS \\
\hline $2 \mathrm{~h}$ & $8.0 \pm 0.548$ & $9.4 \pm 3.249$ & NS \\
\hline $3 \mathrm{~h}$ & $2.6 \pm 0.748$ & $2.2 \pm 1.019$ & NS \\
\hline \multicolumn{4}{|l|}{ Recovery rate (\%): } \\
\hline Total motility & 40.6 & 51.7 & ---- \\
\hline Forward motility & 52.4 & 54.8 & ----- \\
\hline
\end{tabular}

NS: Not significant.

\section{Sperm freezability:}

Results of camel sperm freezability presented in Table (4) showed using AV increased both types of sperm motility percentage (total and forward motility) in post-thawed semen and stored at $37{ }^{\circ} \mathrm{C}$ for $3 \mathrm{~h}$ as compared to EE, though the differences were slight and insignificant. Several investigators found that there is no significant difference in freezability of bull spermatozoa obtained by AV and EE (Colleary and Ehlers, 1964 and Martig et al., 1970).

The present results indicate a marked decrease in total and forward sperm motility, regardless collection technique, in post-thawed semen than in fresh semen. Such findings reflects higher recovery rate of total sperm motility in AV than in $\mathrm{EE}$, and nearly similar recovery rate of forward motility in post-thawed semen collected by both techniques (Table 4).

It is worth noting that the initial motility percentage in fresh semen determines the percentage of forward motility in post-thawed semen, regardless collection technique. In this respect, Zhao et al.
(1994) found that individual sperm motility was 53\% in post-thawed camel semen when they used semen with high initial motility (78\%) using different extenders. Using AV and EE techniques in our study, forward sperm motility was lower (23.8 and $22.4 \%$ ) in post-thawed semen, because initial sperm motility was low (54.8 and 52.4\%) in fresh semen, respectively. Moreover, accepted recovery rate of forward motility was obtained in semen collected by both techniques. Therefore, camel semen collected by $\mathrm{EE}$ is suitable for freezing and can be used for routine artificial insemination scheme.

\section{Blood parameters of camel bulls:}

\section{Concentration of testosterone and some minerals:}

Data in Table (5) showed that using EE significantly decreased concentrations of testosterone $(\mathrm{P}<0.05)$, cholesterol $(\mathrm{P}<0.01)$, magnesium $(\mathrm{P}<0.01)$, zinc $(\mathrm{P}<0.05)$ and inorganic phosphorus $(\mathrm{P}<0.05)$ in blood serum of camel bulls as compared to AV. However, the concentrations of sodium $(\mathrm{Na})$, calcium (Ca) and potassium (K) were not affected 
significantly by collection technique, although they showed a tendency of reduction by EE as compared to AV.

Testosterone is the main sex hormone controlling most of the reproductive functions including libido, later stages of spermatogenesis and the activity of accessory sex glands in male animals (Hafez and Hafez, 2000). The present values of testosterone in blood serum observed in the current study for bulls in EE and AV groups $(2.16 \pm 0.43$ and $1.44 \pm 0.32 \mathrm{ng} / \mathrm{ml}$, respectively) were nearly similar to $1.92 \pm 0.61 \mathrm{ng} / \mathrm{ml}$ reported on dromedary camels during rutting period (Zia-ur-Rahman et al., 2007), while were lower than $4.8 \pm 0.6 \mathrm{ng} / \mathrm{ml}$ as reported earlier for adult camels (Al-Qarawi et al., 2000). These discrepancies can be attributed to differences in the assay protocol used in each study (Zia-ur-Rahman et al., 2007).

Whitlock et al. (2012) found that significant increase in plasma cortisol concentrations in bulls following electro-ejaculation was likely owing to acute stress. In our study, using EE may represent a stress factor on camel bulls during semen collection, which may led to increased corticosterone level from adrenal cortex. Therefore, the observed reduction in testosterone concentration in bulls of EE group may be attributed to that the high levels of corticosterone decreased the number of $\mathrm{LH}$ receptors as well as testosterone production (Bambino and Hsueh, 1981).

It is of interest to note that the obsereved reduction in testosterone concentration in serum of bulls in EE group in this study was associated with increasing of reaction time and ejaculate volume as compared to those in $\mathrm{AV}$ group. In this respect, Aminu Deen (2008) recorded correlation coefficient values for testosterone, copulation time and volume of semen ( $\mathrm{r}=0.847,0.798$ and 0.957 , respectively) showed positive correlation among endocrine and sexual libido parameters.

It is well known that steroid hormones, electrolytes and trace elements all play an important role in controlling the reproductive functions of the male and female animals. The present mineral values are within the normal range of dromedary camels (Zia-ur-Rahman et al. 2007). In camels, plasma testosterone concentrations have been found to be correlated significantly with the contents of $\mathrm{Na}, \mathrm{K}$, $\mathrm{Ca}$ and $\mathrm{Mg}$ in all genital organs but only with epididymal contents of $\mathrm{P}$ and Fe (Al-Qarawi et al., 2000). In dromedary camels, higher serum concentrations of sodium, potassium, calcium and inorganic phosphorus in winter months have been reported earlier (Nazifi et al., 1999). The results of Zia-ur-Rahman et al. (2007) indicated that an increase in serum testosterone concentrations was associated with increased serum and testis levels of $\mathrm{Na}, \mathrm{Ca}$ and $\mathrm{Cu}$, while serum contents of $\mathrm{K}$ decreased with increase in serum testosterone level. In our study, this finding was proved for $\mathrm{Na}$ and $\mathrm{Ca}$ not $\mathrm{K}$. Decreasing testosterone level in bulls of EE group reduced $\mathrm{Na}, \mathrm{Ca}$ and $\mathrm{K}$ contents in blood serum as compared to $\mathrm{AV}$ group, but the differences were not significant.

In the male reproductive system, zinc ions by interacting with DNA of developing spermatids, facilitate the unique packaging of DNA in spermatocytes. During spermiogenesis, a high amount of zinc is incorporated in the outer dense fibers of sperms to protect them from premature oxidation. This may explain increasing sperm livability percentage $(\mathrm{P}<0.05)$ in semen of bulls in $\mathrm{AV}$ than in $\mathrm{EE}$ in relation with $\mathrm{Zn}$ content.

Table 5. Effect of semen collection technique on concentration of testosterone and some minerals in blood serum of dromedary camel bull

\begin{tabular}{lccc}
\hline \multirow{2}{*}{ Item } & \multicolumn{2}{c}{ Collection technique } & \multirow{2}{*}{ Significance } \\
\cline { 2 - 3 } & Electro-ejaculation & Artificial vagina & \\
\hline Testosterone $(\mathrm{ng} / \mathrm{ml})$ & $1.44 \pm 0.32$ & $2.16 \pm 0.43$ & $* *$ \\
Sodium $(\mathrm{mg} / \mathrm{dl})$ & $31.66 \pm 3.357$ & $30.656 \pm 4.673$ & $\mathrm{NS}$ \\
Calcium $(\mathrm{mg} / \mathrm{dl})$ & $5.71 \pm 0.839$ & $5.63 \pm 0.575$ & $\mathrm{NS}$ \\
Potassium $(\mathrm{mg} / \mathrm{dl})$ & $2.70 \pm 0.735$ & $3.35 \pm 0.931$ & $\mathrm{NS}$ \\
Magnesium $(\mathrm{mg} / \mathrm{dl})$ & $1.54 \pm 0.231$ & $2.13 \pm 0.091$ & $* *$ \\
Zinc $(\mu \mathrm{g} / \mathrm{dl})$ & $62.60 \pm 6.416$ & $67.00 \pm 12.984$ & $*$ \\
Inorganic phosphor $(\mathrm{mg} / \mathrm{dl})$ & $71.0 \pm 2.89$ & $76.3 \pm 2.19$ & $*$ \\
\hline
\end{tabular}

NS: Not significant. * Significant at $\mathrm{P}<0.05$. ** Significant at $\mathrm{P}<0.01$.

\section{Concentration of some biochemicals and enzyme activity:}

Data in Table (6) showed that only concentration of cholesterol and AST activity was affected significantly $(\mathrm{P}<0.01)$ by semen collection technique. Concentration of cholesterol was significantly $(\mathrm{P}<0.01)$ decreased and AST activity was significantly $(\mathrm{P}<0.01)$ increased for $\mathrm{EE}$ as compared to AV. However, activity of ALT and ALP in blood serum was not affected significantly by collection technique, although ALP activity showed a tendency of increase by EE as compared to AV. The tendency of higher concentration of total proteins and globulin in AV than in EE group may be due to testosterone concentration. Zia-ur-Rahman et al. (2007) observed that increasing serum testosterone concentration during rutting period may aid in the process of protein synthesis. However, limited literature 
information is available on enzyme activity in serum in the dromedary camel bulla as affected by electroejaculation.

\section{CONCLUSION}

Based on the foregoing results, the proportion of successful semen collections was greater when using EE than AV. Using EE as the collection; ejaculates were obtained with higher volume, total sperm output per ejaculate and membrane integrity and without differences in sperm freezability. The most desirable results for the semen characteristics were obtained using EE as the semen collection method. Electroejaculation is considered as a suitable and repeatable technique for semen collection from dromedary camel bulls when semen collection by conventional artificial vagina is not possible.

Table 6. Effect of semen collection technique on activity of some enzymes and hormones in blood serum of dromedary camel bull

\begin{tabular}{lccc}
\hline \multirow{2}{*}{ Item } & \multicolumn{2}{c}{ Collection technique } & \multirow{2}{*}{ Significance } \\
\cline { 2 - 3 } & Electro-ejaculation & Artificial vagina & \\
\hline Blood biochemicals: & $4.90 \pm 0.341$ & $5.47 \pm 0.313$ & $\mathrm{NS}$ \\
Total protein (g/dl) & $3.04 \pm 0.208$ & $2.70 \pm 0.319$ & $\mathrm{NS}$ \\
Albumin (g/dl) & $1.88 \pm 0.307$ & $2.77 \pm 0.424$ & $\mathrm{NS}$ \\
Globulin (g/dl) & $17.08 \pm 2.390$ & $30.85 \pm 4.030$ & $*$ \\
Cholesterol (mg/dl) & & & $*$ \\
Enzyme activity (IU/l): & $0.81 \pm 0.020$ & $0.76 \pm 0.009$ & $\mathrm{NS}$ \\
AST & $0.53 \pm 0.010$ & $0.56 \pm 0.025$ & $\mathrm{NS}$ \\
\hline ALT & $51.85 \pm 14.428$ & $29.29 \pm 7.347$ & \\
\hline
\end{tabular}

NS: Not significant. * Significant at $\mathrm{P}<0.05$

\section{REFERENCES}

Abbas B., A. Al-Qarawi and A. Al-Hawas, 2000. Survey on camel husbandry in Qassim region, Saudi Arabia: herding strategies, productivity and mortality. Magazine of Animal husbandry and Veterinary Medicine of the Tropical Countries, 53 (3): 293-298.

Abdel-Raouf, M. and M.A. El-Naggar, 1976. Studies on reproduction in camels (Camelus dromedarius). VI. Properties and constituents of ejaculated semen. Proc. $8^{\text {th }}$ Cong. Anim. Reprod. and $\mathrm{Al}$, Cracow, pp. 862-865.

Abdel-Raouf, M. and M.A. (El-Naggar, INITIALS FIRST OR OTHEREWISE IN ALL REFERENCES, BE CONSISTANT) 1978. Studies on reproduction in camels (Camelus dromedarius). VI. Properties and constituents of ejaculated semen. In: VIII $^{\text {th }}$ International Congress on Animal Reproduction and Artificial Insemination. Cracow.

Allain, C.C.; L.S. Poon; C.S. Chan; W. Richmond, and P.C. Fu, 1974. Enzymatic determination of total serum cholesterol. Clin. Chem., 20 (4): 470475.

Al-Qarawi, A.A.; H.A. Abdel-Rahman; M.S. ElBelely, and S.A. El-Mougy, 2000. Age-related changes in plasma testosterone concentrations and genital organs content of bulk and trace elements in the male dromedary camel. Anim. Reprod. Sci., 62: 297-307.

Aminu Deen 2008. Why artificial insemination in dromedaries is not successful? Proceed of the WBC/ICAR, Satellite Meet. Camelid Reprod., Budapest, Hungary, pp: 28-32.
Aminu Deen; Sumant Vyas and M.S. Sahani, 2003. Semen collection, cryopreserva-tion and artificial insemination in the dromedary camel. Animal Reproduction Science, 77 (3-4): 223-233.

Arthur, G.H., 1992. An overview of reproduction in the camelids. Proceedings First International Camel Conference, Dubai, UAE, pp. 109-113.

Arthur, G.H. and A.R. Tigani, 1990. Camel reproduction in Saudi Arabia. New facts from field, abattoir and clinic, In: Proceedings of the Workshop on "Is It Possible to Improve the Reproductive Performance of the Camel" Paris. 10-12 September 1990, p. 23.

Ashby, C.D., C.H. Danzer and R.S. Swerdloff, 1980. Estrogen radioimmunoassay suitable for the monitoring of ovulation induction. Clin. Chem., 26: 1143-1146.

Aubert, M.L. and T. Chard, 1977. Handbook of radioimmunoassay. Edit. Abraham, G.E. Marcal Dekker

Bambino, T.H. and A.J.W. Hsueh, 1981. Direct inhibitory effect of glucocorticoids upon testicular LH receptor and steroido-genesisin vivoandin vitro. Endocrinology, 108: 2142-2148.

Barszcz, K.; D. Wiesetek; M. Wąsowicz, and M. Kupczyńska, 2012. Bull Semen Collection and Analysis for Artificial Insemination. Journal of Agricultural Science, 4 (3): 1-10.

Blom, E. 1983. Sperm morphology with reference to bull infertility. Proceedings of the $1^{\text {st }}$ All-India Symposium on Animal Reproduction (AISAR'83), Ludhiana, India, pp. 61-81.

Bravo, P.W.; M. Ccallo, and Garnica, J. 2000a. The effect of enzymes on semen viscosity in Llamas and Alpacas. Small Ruminant Research,Volume38,Issue1, Pages 91-95. 
Bravo, P.W.; J.A. Skidmore and X.X. Zhao, 2000b. Reproductive aspects and storage of semen in Camelidae. Animal Reproduction Science, 62: 173-193.

Bretschneider, L.H. 1948. A total of norms for use in the morphological evaluation of bull sperm (Trans title). Tijdschr, Diergoneesk, 73:421.

Campbell, R.C.; H.M. Datt, and T.D. Glover, 1956. Nigrosin-Eosin as stain for differentiating live and dead spermatozoa. J. Agric. Sci., 48: 1-8.

Chen, B.X.; X.X. Zhao, and Y.M. Huang, 1990. Freezing semen and A.I. in the Bactrian (Camelus bactrianus). In: Is it possible to improve the reproductive performance of the camel?. Proceeding UGDEC Workshop, Paris.

Colleary, C.W. and M.H. Ehlers, 1964. Frcezabiiity of spermatozoa obtained with the electroejaculator and with the artificial vagina. J. Dairy Sci., 47: 115.

Director, A.; S. Giuliano; M. Carretero; M. Pinto; V. Trasorras, and M. Miragaya, 2007. Electroejaculation and seminal characteristics in llama (Lama glama). Journal of Camel Practice and Research, 14: 203-206.

dromedary camels. Proceeding of the First International Camel Conference, pp

Duncan D.B. 1955. Multiple Range and Multiple Ftest. Biometrics, 11: 1-42.

El-Hassanein, E. 2003. An invention for easy semen collection from dromedary camels, El-Hassanein camel dummy. In: Recent advances in camelid reproduction. Skidmore J.A. and Adams, G.P., Eds, International Veterinary Information Service, Publisher.

Foote, R.H., 1974. Artificial insemination. In: Hafez ESE editors. Reproduction in Farm Animals. $3^{\text {rd }}$ Ed. Philadelphia, PA: Lea and Febiger, p. 409-431.

Franco E.; J. Sumar and M. Varela, 1981. Eyaculacion en la alpaca (Lama pacos). In: Resumenes IV Conv Int sobre Camelidos Sudamericanos, Instituto de la Patagonia; Punta Arenas, Chile. p 4, Abstract.

Gindler, M., 1972. Determination of serum calcium. American Journal of Clinical Pathological, 58: 376.

Giuliano, S.; A. Director,; M. Gambarotta; V. Trasorras and M. Miragaya, 2008. Collection method, season and individual variation on seminal characteristics in Lama glama. Anim. Reprod. Sci. 104: 359-369.

Graham, E.F. and M.M. Pace, 1967. Some biochemical changes in spermatozoa due to freezing . Gryobiology, 4: 75-81.

Graham, E.F. and D.S. Schmehl, 1978. Semen preservation in non-domestic mammals. Symposium of the Zoological Society of London, 43:153-173.

Hafez, B. and E.S.E. Hafez, 2000. Reproduction in Farm Animals, $7^{\text {th }}$ ed. Philadelphia: Lippincott Williams and Wilkins, USA, pp. 431-442.
Hemeida, N.A. 1972. Studies on semen characteristics in bucks. M.Sc. Thesis, Faculty of veterinary Medicine, Cairo University, Egypt.

Hemeida, N.A.; M.M. Al-Eknah,; S.T. Ismail, and A.Kh. Al-Haider, 2001. Anew technique for collection of semen from dromedary camels. Emir.J. Agric. Sci. 13:18-22.

Hughes, C.M.; S.E.M Lewis; V.J. McKelvey-Martin, and W. Thompson, 1997. Reproducibility of human sperm DNA measurements using a single cell gel electrophoresis assay. Mutation Research, 374:261-268

Hughes, C.M.; S.E.M. Lewis; V.J. McKelvey-Martin, and W. Thompson, 1996. A comparison of baseline and induced DNA damage in human spermatozoa from fertile and infertile men, using a modified comet assay. Mol. Hum. Reprod., 2: 613-619.

Kononov, V.P., 1968. Cytophotometric investigation of dynamics of deoxyribonucleic acid content in boars spermatozoa when semen is preserved outside the organism. Dki, Soviet Ush. K. VI. International Congress on Reproduction and AI, Moscow, 32.

Kuttner, T. and L. Lichtenstein, 1930. Determination of inorganic phosphorus. J. Biological Chemistry, pp 86-671.

Lichtenwalner, A.B.; G.L. Woods, and J.A. Weber, 1996. Seminal collection, seminal characteristics and Artificial Insemination. Ed Samper W.B., Sounders Corporation. Philadelphia, pp 81-90.

Mann, T. 1964. The biochemistry of semen and of the male reproductive tract. $2^{\text {nd }}$ Ed., London, Methuen, p. 493.

Marai, I.F.M. and A.E.B. Zeidan, 2007. Review Artificial Insemination in Camelidae. Tropical and Subtropical Agroecosystems, 7: 1-13.

Martig, R.C.; J.O. Almquist, and J. Foster, 1970. Reproductive capacity of beef bulls. V. Fertility and freezability of successive ejaculates collected by different methods. J. Anim. Sci., 30: 60-62.

Morton, K.M.; Z. Gibb; M. Bertoldo, and W.M. Chis Maxwell, 2009. Effect of diluent, dilution rate and storage temperature on longevity and functional integrity of liquid stored alpaca (Vicugna pacos) semen. Journal of Camelid Science, 2: 15-25.

Musa, B.; H. Sieme,; H. Merket, and B.E.D. Hago, 1992. Artificial Insemination in Dromedary Camels. Proc. $1^{\text {st }}$ international Camel Conference, February 1992, Dubai, U.A.E.

Nazifi, S.; H.R. Gheisari, and H. Poorabbas, 1999. The influence of thermal stress on serum biochemical parameters of dromedary camels and their correlation with thyroid activity. Comp. Haemat. Intern., 9: 49-54.

Niasari-Naslaji A.; S. Mosaferi; N. Bahmani; A.A. Gharahdaghi; A. Abarghani; A. Ghanbari and A. Gerami, 2006. Effectiveness of a tris-based extender (SHOTOR diluent) for the preservation of Bactrian camel (Camelus bactrianus) semen. Cryobiology, 53: 12-21. 
NRC 1981. National Research Council. Nutrient Requirements of Domestic Animals. Nutrient Requirements of Goats. National Research Council, National Academy Press, Washington D.C., USA.

Pratt, I.J. 1978. Steroid in clinical chemistry. Clinical Chemistry, 24: 1869-1890.

Ritman, S. and S. Frankel, 1957. A colorimetric methods for the determination of serum glutamic oxaloacetic transaminase. American Journal of Clinical and Pathology, 2: 56-61.

SAS, 2002. SAS Institute Inc., Cary, NC, USA. NOTE: SAS Proprietary Software Version 9.00.

Shamsi, M.B.; S. Venkatesh,; M. Tanwar,; G. Singh,; S. Mukherjee,; N. Malhotra,; R. Kumar,; N.P. Gupta,; S. Mittal, and R. Dada, 2010. Comet assay: A prognostic tool for DNA integrity assessment in infertile men opting for assisted reproduction. Indian J Med Res 131, May 2010, pp 675-681.

Sieme, H.; H. Merkt; B. Musa; B. Hago and T. Willem, 1990. Liquid and deep freeze preservation of camel semen using different extenders and methods. Proc. the workshops in it possible to improve the reproductive performance of the camel, Paris. pp. 273-284.

Skidmore, J.A.; K.M. Morton and M. Billah, 2013. Artificial insemination in dromedary camels. Anim. Reprod. Sci .136:178-186.

Sumar, J. 1991. Fisiologia de la de la reproduccion del Macho y Macho y Manego reproductivo. In: Avances y perspectivas del concimiento de los Camelidos Sudamericanos. Oficina Regional de la FAO para America Latina y el Caribe, Satiago, Chile.

Taylor, F.H.L. and E.R. Shea, 1930. The determination of potassium in blood serum. J. Biol. Chem. 87: 27-32

Tibary, A. and A. Anouassi, 1997. Theriogenology in camelidae. $1^{\text {st }}$ ed. Ministry of Agriculture and Information, UAE. pp. 49-74.

Tibary, A. and M.A. Memon, 1999. Reproduction in the male South American camelidae. Journal of camel practice and Reach, 6:235-245.

Tingari, M.D.; M.M. El-Manna; A.T.A. Rahim; A.K. Ahmed, and M.H. Hamed, 1986. Studies on camel semen. I. Electroejaculation and some aspects of semen characteristics. Anim. Reprod. Sci., 12: 213-222.

Trinder, P. 1951. A rapid method for the determination of sodium in serum. Analyst, 76: 596.

Tura I.; G. Kuria; H.K. Walaga and J. Lesuper, 2010. Camel Breeding Management among the Somali, Sakuye, Gabbra and Rendille Pastoralists of Northern Kenya, Tropentag, September 14-16, 2010, Zurich, Switzerland. Abstract.

Watson, P.F. 1975. Use of a Giemsa stain to detect changes in acrosomes of frozen ram spermatozoa. Vet. Rec., 97: 12-15.

Weichselbaum, T.F. 1946. An accurate and rapid method for the determination of protein in small amount of blood serum and plasma. American Journal of Clinical Pathological, 16: 40-90.

Doumas, B.T. and H.G. Biggs, 1976. Standard Methods of Clinical Chemistry, Academic Press, N.Y., p. 175.

Westendorf, P.; L. Richter, and H. Treu, 1975. Zur Tiefgefrierung von Ebersperma: Labor-und Besamungsergebniss mit dem Hulsenberger Pailletten Verfahren. Dtsch. Tierarztl. Wschr., 82:261-267.

Whitlock, B.K.; E.A. Coffman; J.F. Coetzee, and J.A. Daniel, 2012. Electroejaculation increased vocalization and plasma concentrations of cortisol and progesterone, but not substance $\mathrm{P}$, in beef bulls. Theriogenology, 78 (4): 737-746.

Willis, J.W. 1960. The determination of metals in blood serum and tissues by atomic absorption spectrophotometry. Spactroch. Acta., 16: 259272.

Zeidan, A.E.B. 2002. Semen quality, enzymatic activities and penetrating ability of spermatozoa into she- camel cervical mucus as affected by caffeine addition. J. Camel Practice and Res., 9:153-161.

Zhao, X.X.; Y.M. Huang, and B.X. Chen, 1994. Artificial insemination and pregnancy diagnosis in the Bactrian camel (Camelus bactrianus). J. Arid Environments, 26: 61-65.

Zia-ur-Rahman; N. Ahmad; A.B. Shazia,; N. Akhtar, and D .Haq, 2007. Serum hormonal, electrolytes and trace element profiles in the rutting and nonrutting one-humped male camel (Camelus dromedarius). Anim. Reprod. Sci., 101: 172-178. 
القدرة التجميديه وسلامة الحامض النووى للحيوانات المنوية لذكور الجمال وحيدة السنام فى السائل المنوى المجمع

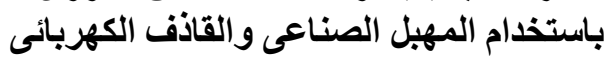

طارق حسن مصطفى1، عاطف محروس عبد السلام، ضياء الدين عبد المؤمن البدرى²، عبير محمد أنور2 1 1- معزة بحوث الإنتاج الحيوانى، مركز البحوث الزراعية، وزارة الزراعة، 2- معهل بحوث التتاسليت الحيوانية، مركز البحوث الزراعية،

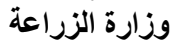

قورنت طريقتين لجمع السائل المنوي من الإبل (القاذف الكهربائي مقابل المهيل الإصطناعي التقليدي) في تأثير هم على وقت رد الفعل،

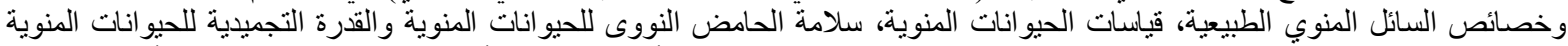

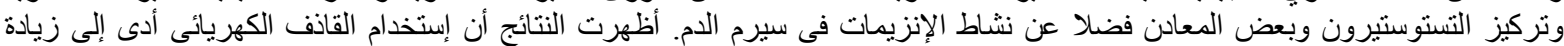

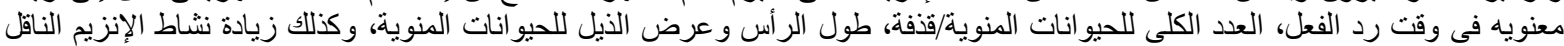

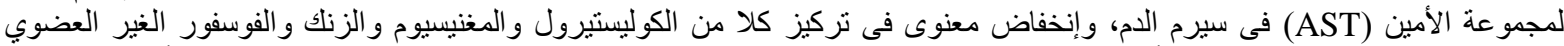

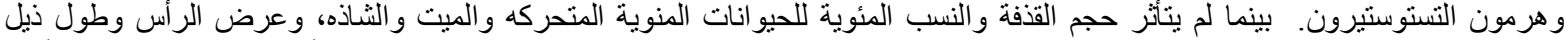

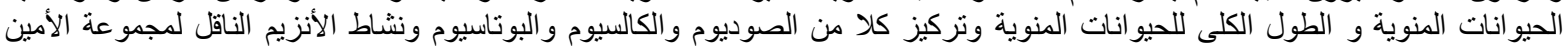

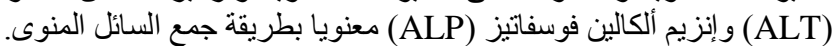

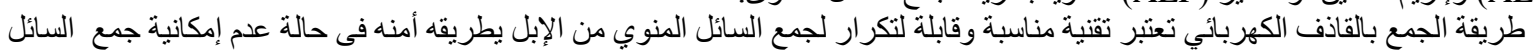
المنوي من الإبل بطريقة المهيل الإصطناعي التقليدي. 